\title{
The scientific and legal significance of the methods of realization state land control
}

\author{
Saliev Mirza Abdurachmanovich, \\ An independent scientist Tashkent state university of Law
}

http://dx.doi.org/10.26739/2573-5616-2017-7-7-2

\begin{abstract}
The present article is devoted to the consideration and analysis of the scientific and legal significance of methods for the implementation of state land control, including such forms as monitoring of the state of land, environmental expertise of lands statute. In the process of studying the scientific apparatus, the author gave relevant suggestions and recommendations for improving the practice of land control.
\end{abstract}

Keywords: Land Resources, Land Code, State Land Control, Monitoring, Expertise, Control Methods.

peaking about the scientific and legal significance of ways to

implement state land control over the use and protection of land, it is important to determine what actions with regard to land can constitute types of similar methods. V. Petrov, one of the first to study the theoretical issues of state land control, dwelt on its two main forms, that is, monitoring of land and land expertise[1].

If we pay attention to the opinion of $\mathrm{M}$. Brinchuk regarding the forms of environmental control, he does not include monitoring of land in the system of this control. "Inclusion in the environmental monitoring system of the state environmental monitoring service would be groundless", writes M. Brinchuk, - since monitoring is an independent function of public administration in the field of environmental protection. "Unlike state 
environmental expertise and environmental licensing, which perform control functions, monitoring does not fulfill this function, it is a passive function of the state administration, within which state power and state coercion are not manifested"[2].

In the rules of the existing environmental laws of the Republic of Uzbekistan, one can see the reflection of the norms establishing the forms of state land control, data in the legal literature. Thus, in the Law "On Nature Protection", the IV section is devoted to the issues of "normative regulation of the quality of the environment", VI section - "ecological expertise", article 28 - "environmental monitoring", article 33 environmental licensing, article 46 - "environmental certification". The relevant special laws are devoted to separate forms of state environmental control (for example, the Law "On Environmental Expertise").

When implementing state land control, such forms as land monitoring, land cadastre, state land registration, application of legal responsibility are used. As one of these methods, land monitoring is considered a preliminary stage of ensuring state control over the use and protection of land. So, conducting land monitoring is the main way of exercising state control.

It should be noted that there is no uniform opinion in the legal literature regarding the relevance of land monitoring to the public administration system. For example, M.M. Brinchuk advanced the idea that the state service for monitoring the state of the environment is an independent function of state administration[3]. Consequently, it does not recognize land monitoring as a way of implementing state land control. At the same time, as V.V. Petrov writes: "From the point of view of national development, monitoring should be understood in a broad sense, which is, not monitoring the state of the environment, but checking the implementation of measures for environmental protection and compliance with legislative acts"[4].

Focusing on the above ideas and views, when including land monitoring in the public administration system, V.V. Petrov's ideas can be taken as a scientific basis. In our view, recognizing land monitoring as a way of implementing state land control, we should rely on the following grounds. Firstly, the fundamental essence of land monitoring is not in the simple observation of the environment, but in the collection of information. According to Article 14 of the Land Code, land monitoring is a system for monitoring the state of the land fund for the timely identification of changes, assessing land, preventing and eliminating the consequences of negative processes. Consequently, monitoring of land is a method of control 
that serves to ensure the quality of land resources, which are the main object of public administration.

Secondly, the state monitoring of lands is carried out by the State Committee for Nature Protection, which is a body of state administration. In addition, certain functions related to land monitoring are implemented by special government bodies authorized to implement public administration. These special bodies carry out land monitoring as their management function.

Thirdly, taking into account that when applying measures of the impact of state land control, the results of land monitoring are considered its basis, it is advisable to recognize it as one of the ways of state land control.

Fourthly, as a way of state land control, the monitoring of land entrusts its subjects with certain additional tasks. Conclusions obtained as a result of land monitoring, serve as the basis for taking decisions by the relevant government body. At the same time, land monitoring can be recognized as a method of state land control only if it is carried out by a special competent state body.

In accordance with Article 14 of the Land Code of the Republic of Uzbekistan, monitoring of land - there is a system for monitoring the state of the land fund for the timely identification of changes, assessing land, preventing and eliminating the consequences of negative processes. Observation of changes in the composition of lands consists in monitoring the targeted use of land, soil fertility, salinity, soil erosion, water logging, pollution, aridity or moisture, unauthorized seizure of lands, compliance with environmental protection requirements. In general, land monitoring is a set of relevant activities related to state land control, considered as an independent object in the environmental monitoring system and realized by the special competent authorities of the state.

In the Republic of Uzbekistan, land monitoring is carried out by the State Committee of the Republic of Uzbekistan for Land Resources, Geodesy, Cartography and State Cadastre, the State Committee for Nature Protection, with the participation of the Ministry of Agriculture and Water Resources, the State Committee for Architecture and Urban Planning, the Main Directorate of Hydrometeorology under the Cabinet of Ministers (Glavgidromet"), The State Committee for Geology and Mineral Resources and relevant ministries and departments. The State Committee of the Republic of Uzbekistan for Land Resources, Geodesy, Cartography and State Cadastre coordinates the activities of these ministries and departments, and also carries out the tasks of summarizing information on land monitoring. 
In the implementation of state land control, the state land cadastre is of particular importance. Special state bodies by maintaining the land cadastre provide state control over effective use and protection of land.

On the concept of the state land cadastre in the legal literature there are different opinions. At the same time, for disclosing the concept of the state land cadastre, one should refer to its etymological mind. Thus, in the legal encyclopedia of Uzbekistan, the notion of a cadastre is given a definition in the form of a systematic collection, a list, a register of constantly updated information and documents regarding geographical location, legal status, quantitative and qualitative indicators, and prices of a certain type of natural, economic or other object[5].

I.S. Kaurichev in his work "Soil Science" confirms the origin of the word cadastre from the French "cadastre" (registration)[6]. A well-known scientist, environmentalist A.Nigmatov gives the word cadastre the following definition: cadastre is a system of updated information and documents regarding the geographical location, legal status, quantity, quality characteristics and price of a certain type of natural, economic or other object[7].

The concept of the state land cadastre is also given in the Law of the Republic of Uzbekistan "On the state land cadastre"[8]. According to Article 3 of this Law, the state land cadastre is the main component of the Unified System of State Cadastres and is a system of information and documents on the natural, economic, legal regime of land, their categories, quality characteristics and values, location and size of land plots, owners, users, leaseholders and owners.

According to the definition proposed by the scientist R.S. Tashbaeva, "The State Land Cadastre of the Republic of Uzbekistan is a regularly updated and streamlined system of data on the state of quality and quantity of land resources, the price of land resources, soil fertilization, registration of land plots for registration, submission of data of the state land cadastre, as well as use of cadastral data and other necessary information"[9].

Article 15 of the Land Code of the Republic of Uzbekistan defines the purpose of maintaining the state land cadastre. In accordance with it, the state land cadastre is intended to provide the Cabinet of Ministers of the Republic of Uzbekistan, local government authorities, interested legal entities and individuals with information on land in order to regulate land relations, organize the rational use and protection of land, land management, justify the size of payment for land, assessment of economic activity. 
In the special scientific literature on land law there are other opinions and ideas regarding the nature of the state land cadastre. In particular, as O. Tursunov correctly points out, one should not lose sight of the fact that not every official document, as well as their system, makes sense of the word cadastre. In addition, the documents mean only information received regarding the natural, economic, legal and other status of the land. Hence, this term should be applied not to the essence and content of the state land cadastre, but rather to its composition[10].

A number of authors list the measures for state registration of rights to land plots, accounting for the quantity of land quality, soil classification, systematization, preservation and updating of data on the value of land, as well as the land cadastre, mandatory provision of these data for use and protection as the main objectives of the state land cadastre land, the allocation and seizure of land, the determination of the amount of payments for the use of land, work on land management, valuation of economic activity as well as the implementation of other measures on land use and protection[11].

As follows from the current legislation, in the acts of the state land cadastre the surname, name and patronymic of the landowner (land user, owner), the form of ownership of the land, cadastral number, the date of registration of the right to the land plot, the date of issuance of documents concerning the ownership right, the terms of land ownership, land use, the purpose and objectives of the provision of land, a scheme indicating the point of the boundary of the land, the definition of adjacent land, easements, limitations when used and the land, the indicators characterizing the quantitative and qualitative state of the land, its economic price.

The content of the state land cadastre consists of the following: (a) state registration of rights to land plots; b) accounting for the quantity and quality of land (determining the soil bonitet); c) assessing the value of land; d) systematization, storage and updating of information on the state land cadastre.

Land administration plays an important role in the implementation of state land control. It should be noted that the basis of land management is the issues of strict compliance with the requirements of land legislation, accounting for the use and protection of agricultural land are carried out in accordance with the natural and agricultural zoning of the land, as well as ensuring equal rights and economic conditions for landowners, land users and tenants, depending on the form of ownership, as well as the quality and location of land. In addition, the definition of land tax, taking 
into account the number (size) of the land plot, quality, cost and location, payment of rent, and collection of information on compensation for damage suffered by the economic entity as a result of land allocation is also considered the main goal of land management.

According to the current land legislation, the work on land management is carried out by the land management bodies by decision of the Cabinet of Ministers of the Republic of Uzbekistan, local government authority or by applications of legal entities and individuals. The activity of the land management bodies is divided into the national, sectoral, departmental, inter-farm and intraeconomic types. When implementing national land management, the main indicators of targeted use of land territories are determined; large territorial comprehensive plans for effective use and protection of land reserves are being developed; in regions, districts, cities or other settlements, separate effective methods and forecasts of land use are developed or planned; Targeted programs for improvement (melioration), restoration (reclamation) of lands, combating water and wind erosion are being developed. Also, in the conduct of nationwide land management on a scientific basis, long-term and short-term plans and forecasts for inter-sectoral land allocation are developed. At the same time, the future needs of the branches of the national economy are studied in land reserves, unused or poorly used lands are determined.

Article 12 of the Land Code of the Republic of Uzbekistan defines four types of work on land management: 1) predictive; 2) pre-project; 3) inter-farm; 4) on-farm. These types of land management differ in the location of land plots (country, region, district, city, farm, etc.), a legal act that is the basis for conducting land management works (decision of the government, applications of legal entities or individuals), the timing of implementation (forecast, pre-project, post-project, etc.), focus on economic entities (inter-farm and intra-farm) or non-directional (forecast, pre-project) and other aspects.

Based on the foregoing, it can be concluded that in land management works the registration of all lands and the determination of unused or inefficiently used, as well as non-designated lands; assessment of land resources, preparation of land management documents for the use and protection of land; the implementation of measures to establish the value (bonitet) of land are part of important methods of state land control.

In the system of methods of state control over the use and protection of land, a special place is occupied by state registration of rights to land plots. 
The state registration and execution of acts concerning the ownership, possession, use and lease of land plots is organized in order to protect the property rights of legal entities and individuals, as well as reasonable and effective accounting of land resources, land transactions, taxation, etc.

It should be noted that the state registration of rights to land is official and mandatory, on this basis the rights of legal entities and individuals to land plots are determined, they can only be recognized from the moment of registration. State registration of the rights of legal entities and individuals to land plots can be carried out on their initiative, or in the process of implementing a planned cadastral survey of land plots.

State registration of rights to land plots is carried out by entering information on rights to land in districts, cities, confirmed by acts of registration in the State Register. Legal acts that properly approve, provide, modify, restrict or terminate rights to land plots issued in accordance with the requirements of the legislation of the Republic of Uzbekistan shall be recognized as registration objects. State registration of rights to land plots is carried out by the relevant territorial state bodies at the location of land plots.

\section{References:}

1.Petrov V.V. Ecology and law. P.125-142.

2. Branchuk M.M. Ecological right. C.449-450.

3. Brinchuk M.M. Ecological right. - M., 1990. - P. 449.

4. Petrov V.V. Ecology and law. - M., 1991. - P. 130.

5. Legal encyclopedia of Uzbekistan. /Answer. Ed. N.Tuychiev. -T.: Adolat, 2010. - P. 236

6. Soil science. Ed. prof. I.S. Kauricheva. - M.: Agropromizdat, 1989

7. Nigmatov A. Land Law. Textbook. -T .: Tashkent Islamic University, 2001. P.90.

8. Report of the Oliy Majlis of the Republic of Uzbekistan 1998, No. 9, P.165.

9. Tashbaeva RS Legal regulation of the management of natural cadastres of the Republic of Uzbekistan: Author's abstract. diss. ... cand. jurid. sciences. -T., 2009. - P. 9.

10. See: Tursunov O. Problems of legal support of the state land cadastre: Author's abstract. diss. ... cand. jurid. sciences. - Т.: ТДЮИ, 2012. - С.27.

11. See: Nazimkina O.V. The emergence of rights to land: Author. diss. ... cand. jurid. sciences. - M: 1999; Sai S.I. Regulation of land and property relations on the basis of perspective cadastral systems: Author's abstract. diss. ... cand. econ. sciences. -M.: RAGS, 2000 